\title{
Isotope Dilution Analysis for Urinary Fentanyl and Its Main Metabolite, Norfentanyl, in Patients by Isotopic Fractionation Using Capillary Gas Chromatography
}

\author{
Shoji Sera, Tsuyoshi Goromaru, Teruko Sameshima*, \\ Koichi KAWASAKI* and Toshiyuki ODA* \\ Faculty of Pharmacy and Pharmaceutical Sciences, Fukuyama University \\ Gakuen-cho, Fukuyama-shi, Hiroshima Pref. 729-0292, Japan \\ * Kagoshima University School of Medicine \\ 8-35-1, Sakuragaoka, Kagoshima-shi Kagoshima Pref 890-0075, Japan
}

Received February 6, 1998

\begin{abstract}
Isotope dilution analysis was applied to determine urinary excretion of fentanyl (FT) and its main metabolite, norfentanyl (Nor-FT), by isotopic fractionation using a capillary gas chromatograph equipped with a surface ionization detector (SID). Urinary FT was determined quantitatively in the range of $0.4-40 \mathrm{ng} / \mathrm{ml}$ using deuterium labeled $F T\left(F T-{ }^{2} \mathrm{H}_{19}\right)$, as an internal standard.

We also performed isotope dilution analysis of Nor-FT in urine. N-Alkylation was necessary to sensitively detect Nor-FT with SID. Methyl derivative was selected from 3 kinds of $N$-alkyl derivatives to increase sensitivity and peak resolution, and to prevent interference with urinary compound. Nor-FT concentration was quantitatively determined in the range of $10-400 \mathrm{ng} / \mathrm{ml}$ using deuterium labeled Nor-FT (Nor-FT $\left.{ }^{2} \mathrm{H}_{10}\right)$. No endogenous compounds or concomitant drugs interfered with the detection of FT and Nor-FT in the urine of patients. The present method will be useful for pharmacokinetic studies and the evaluation of drug interactions in FT metabolism.
\end{abstract}

Key Words : capillary gas chromatography, isotope dilution analysis, fentanyl, norfentanyl, urinary concentration, deuterium label, isotopic fractionation

\section{Introduction}

Fentanyl[1-(2-phenethyl)-4- $N$-( $N$-propionylanilino)piperidine, FT] is a synthetic narcotic analgesic more potent than morphine, and it has been widely used during surgery. By gas chromatography-mass spectrometry (GC-MS) combine with the stable isotope tracer technique, we have identified five urinary metabolites of FT in rats ${ }^{1)}$, three of them were also detected in the urine of surgical patients who had received FT $^{2}$. Furthermore, we have detected some FT metabolites with phenethyl and propionyl group oxidation in isolated hepatocytes from rats and guinea pigs ${ }^{3)}$. Urinary excretion of unchanged FT, $N$-propionyl- anilinopiperidine (Nor-FT) and 1-(p-hydroxyphenethyl)-4-( $N$-propionylanilino)piperidine were excreted, as expressed as dosage percentage, at $1-4 \%, 8-25 \%$ and $3-6 \%$, respectively, in surgical patients under high dose FT anesthesia ${ }^{4}$.

GC-MS in conjunction with stable isotope techniques enables structural information to be obtained. Concentration can also be accurately measured using selected ion monitoring. However, the major problems of GC-MS equipment are the limited availability and expensiveness. Recently, we have reported that isotopic fractionation techniques using capillary GC to measure deuterium labeled compounds is an alternative to GC-MS, and we have applied this technique to isotope 
dilution analysis of drugs and metabolites 5)-8). We previously showed the isotopic fractionation of FT and deuterium labeled FT'). Furthermore, we observed that the quantitative determination of serum FT in patients using this technique is accurate and reproducible ${ }^{10)}$. In the present study, this technique was applied to determine urinary FT and its main metabolite, Nor-FT.

\section{Experimental}

\subsection{Materials}

FT and 1-nonadeuterophenethyl-4- $N$-pentadeuteropropionyl-pentadeuteroanilino-piperidine(FT${ }^{2} \mathbf{H}_{19}$ ) were prepared as described previously ${ }^{9)} . \mathrm{N}$ Propionyl-anilinopiperidine (Nor-FT) and $\mathrm{N}$ pentadeuteropropionyl-pentadeuteroanilinopiperidine (Nor-FT- ${ }^{2} \mathrm{H}_{10}$ ) were synthesized as described previously9) and purified as propionate. Nor-FT propionate and Nor-FT- ${ }^{2} \mathrm{H}_{10}$ propionate have melting points of $116-120^{\circ} \mathrm{C}$ and $113-120$ ${ }^{\circ} \mathrm{C}$, respectively. The molecular ions of the free forms were detected at $m / z 232$ in Nor-FT and $m / z 242$ in Nor-FT- ${ }^{2} \mathbf{H}_{10}$ by their EI-mass spectra. Found values (calculated values in parenthesis) from elemental analysis were $\mathrm{H}: 8.49$ (8.55)\%, C: 66.32 (66.64)\% and N: 9.05 (9.14)\% in Nor-FT propionate, and $\mathrm{H}: 5.10$ (5.10)\%, C: 64.30 (64.52)\%, N: 8.97 (8.85)\% and D: 6.20 (6.36)\% in Nor-FT- ${ }^{2} \mathbf{H}_{10}$ propionate. The deuterium labeled position was identified from the disappearance of signal when comparing ${ }^{1} \mathrm{H}-\mathrm{NMR}$ spectrum with Nor-FT. The chemical structures of Nor-FT and its analogues are shown in Fig. 1.

\section{$2 \cdot 1 \cdot 1$ Synthesis of Nor-FT and Nor-FT- ${ }^{2} \mathrm{H}_{10}$} derivatives

Methyl derivatives of Nor-FT (Nor-FT-Me) and Nor-FT- ${ }^{2} \mathrm{H}_{10}$ (Nor-FT- ${ }^{2} \mathrm{H}_{10}-\mathrm{Me}$ ) were synthesized as follows. Nor-FT or Nor-FT- ${ }^{2} \mathrm{H}_{10}(0.3$ g) was dissolved in $9 \mathrm{ml}$ of methanol. Dimethyl sulfate $(140 \mu 1)$ and $60 \mathrm{mg}$ of calcium oxide was

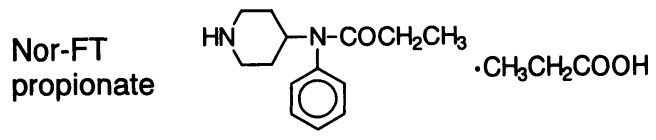

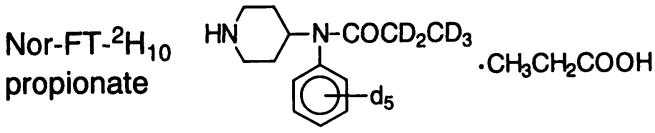

Nor-FT-Me

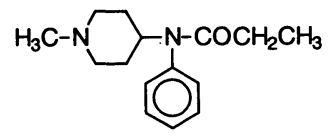

Nor-FT-Et

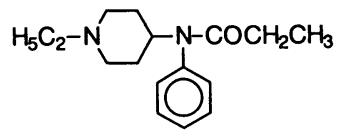

Nor-FT-Ben

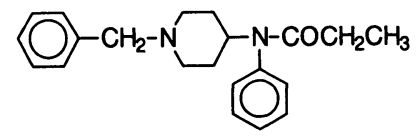

Fig. 1 Chemical structures of Nor-FT and its analogues.

added and the solution was refluxed for $1 \mathrm{~h}$. The reaction mixture was evaporated off, dissolved in $3 \mathrm{ml}$ of ethyl acetate, and washed with $3 \mathrm{ml}$ of $\mathrm{H}_{2} \mathrm{O}$. This solution was evaporated and the residue was sublimated at $150-200^{\circ} \mathrm{C}$ under reduced pressure to produce $0.07 \mathrm{~g}$ of Nor-FT or Nor-FT- ${ }^{2} \mathbf{H}_{10}$. Ethyl derivatives of Nor-FT (NorFT-Et) and Nor-FT- ${ }^{2} \mathrm{H}_{10}$ (Nor-FT- ${ }^{2} \mathrm{H}_{10}-\mathrm{Et}$ ) were synthesized using the above procedure using diethyl sulfate instead of dimethyl sulfate.

Benzyl derivatives of Nor-FT (Nor-FT-Ben) and Nor-FT $-{ }^{2} \mathrm{H}_{10}$ (Nor-FT- ${ }^{2} \mathrm{H}_{10}$-Ben) were synthesized using a similar method for 1-benzyl-4- $\mathrm{N}$ $(N$-propionylanilino)piperidine as previously reported").

Chemical structures were identified by EI-mass spectra and the molecular ions were detected at $m / z \quad 246$ in Nor-FT-Me, $m / z \quad 256$ in Nor-FT- ${ }^{2} \mathbf{H}_{10}-\mathrm{Me}, m / z 260$ in Nor-FT-Et, $m / z 270$ in Nor-FT- ${ }^{2} \mathrm{H}_{10}$-Et, $m / z 322$ in Nor-FT-Ben, and 
$m / z 332$ in Nor-FT- ${ }^{2} \mathbf{H}_{10}$-Ben. The purities of these compounds were confirmed by gas chromatography. The chemical structures of these derivatives are shown in Fig. 1.

\section{$2 \cdot 2$ Gas chromatographic conditions}

Gas chromatographic analysis was performed with a fused-silica capillary column $(25 \mathrm{~m}, 0.22$ mm i.d.) with chemically bounded methylpolysiloxane and a film thickness of $0.25 \mathrm{~mm}$ (HicapCBP1-M25-025, Shimadzu). Theoretical plates for the CBP1 columns were 100000 (25 m, pentadecane). A Shimadzu model GC-14A gas chromatography equipped with a surface ionization detector (SID) was used. The inlet system used was solvent less of moving-needle type. The retention time was measured by a data processor, Shimadzu model C-R5A Chromatopac. The injection port was kept at $290^{\circ} \mathrm{C}$, the column was operated at $180^{\circ} \mathrm{C}$ for Nor-FT or $260^{\circ} \mathrm{C}$ for FT and the detector temperature was $320^{\circ} \mathrm{C}$. The carrier gas was helium at $1.4 \mathrm{ml} / \mathrm{min}$.

\subsection{Deactivation of glassware surface}

Glassware surface was deactivated to prevent FT losses by adsorption. The glassware was silanized. The glass vials and tubes for sample preparation were coated with 1 or 2 drops of dichlorodimethylsilane (Tokyo Kasei). After being in contact with the vapor of the reagent for overnight, the glass vials were rinsed with dry toluene and absolute methanol. Subsequently, they were rinsed with ethyl acetate and air-dried.

\subsection{Extraction of FT from urine}

The determination of FT concentration in urine was performed by a similar method in previous report $^{10)}$. Urine $(1 \mathrm{ml})$ was added to $0.5 \mathrm{ml}$ of $1 \mathrm{~N}$ $\mathrm{NaOH}$ and was extracted with $1 \mathrm{ml}$ of ethyl acetate, which contained $20 \mathrm{ng}$ of $\mathrm{FT}-{ }^{2} \mathrm{H}_{19}$, by shaking for $10 \mathrm{~min}$. After centrifugation (4000 $\mathrm{rpm} / 5 \mathrm{~min}$ ), the supernatant put in a glass vial and was back-extracted with $0.5 \mathrm{ml}$ of $1 \mathrm{~N} \mathrm{HCl}$ using a vortex mixer. After centrifugation (3000 $\mathrm{rpm} / 5 \mathrm{~min}$ ), the ethyl acetate layer was removed. The residual aqueous layer was added to $0.5 \mathrm{ml}$ of $2 \mathrm{~N} \mathrm{NaOH}$ and was extracted by $200 \mu 1$ of hexane using a vortex mixer. After centrifugation (3000 $\mathrm{rpm} / 5 \mathrm{~min}$ ), the hexane layer was transferred to another glass vial and was evaporated until dry by a $\mathrm{N}_{2}$ stream. The residue was dissolved in $10 \mu 1$ of methanol and the methanol solution $(1-3 \mu 1)$ was injected in to a gas chromatograph.

2.5 Extraction and derivation procedure of Nor-FT

Urine $(1 \mathrm{ml})$ was added to $0.5 \mathrm{ml}$ of $1 \mathrm{~N} \mathrm{NaOH}$ and was extracted with $1 \mathrm{ml}$ of ethyl acetate, which contained $200 \mathrm{ng}$ of Nor-FT $-{ }^{2} \mathrm{H}_{10}$, by shaking for $10 \mathrm{~min}$. After centrifugation (4000 rpm/5 min), the supernatant was put in a glass tube and evaporated until dry by a $\mathrm{N}_{2}$ stream. The residue was dissolved in $2 \mathrm{ml}$ of methanol. To the solution, $50 \mu 1$ of methanol containing $4 \%$ of dimethyl sulfate was added. After heating at $35^{\circ} \mathrm{C}$ for $60 \mathrm{~min}$, the reaction mixture was evaporated until dry. The residue was dissolved in $1 \mathrm{ml}$ of $5 \mathrm{~N}$ $\mathrm{NaOH}$ and the solution was extracted with $1 \mathrm{ml}$ of ethyl acetate using a vortex mixer. After centrifugation (4000 rpm/5 min), the supernatant was put in a glass vial and was back-extracted with 0.5 ml of $1 \mathrm{~N} \mathrm{HCl}$ using a vortex mixer. After centrifugation $(3000 \mathrm{rpm} / 5 \mathrm{~min})$, the ethyl acetate layer was removed. The residual aqueous layer was added to $0.5 \mathrm{ml}$ of $2 \mathrm{~N} \mathrm{NaOH}$ and was extracted with $200 \mu 1$ of ethyl acetate using a vortex mixer. After centrifugation (3000 rpm/5 min), the ethyl acetate layer was transferred to another glass vial and the solution $(1-3 \mu 1)$ was injected in to a gas chromatograph. 


\section{$2 \cdot 6$ Collection of urine samples}

All urine samples were obtained from surgical patients that received FT, who had normal hepatic and renal functions. Anesthesia was carried out as previously described ${ }^{10)}$. FT was i.v. administered $(5 \mu \mathrm{g} / \mathrm{kg})$ by a bolus injection as fentanyl citrate (Fentanest, Sankyo). Urine samples were collected 7 times across $3 \mathrm{~h}$ after FT administration by urine bag exchange. Collected urine samples were transferred to silanized tubes, capped, sealed with Parafilm, and was stored for 9 - 15 days at $4{ }^{\circ} \mathrm{C}$ until analysis.

\section{Results and Discussion}

In our previous report ${ }^{10)}$, the advantage of the isotope dilution analysis for serum FT determination was demonstrated by comparison with other FT analogues which substituted a propionyl group with an acetyl group or a phenethyl group with a benzyl group as the internal standard. Furthermore, we indicated that the isotopic fractionation method using capillary GC with SID is accurate for the isotope dilution analysis of FT.

In this study, we applied isotope dilution analysis to determine urinary excretion of FT from patients. Six standard urine samples, which contained 0.4 to $40 \mathrm{ng} / \mathrm{ml}$ of FT with $20 \mathrm{ng} / \mathrm{ml}$ of FT- ${ }^{2} \mathbf{H}_{19}$ were prepared. The extraction procedure used was similar to that used for serum FT analysis. The calibration curve was estimated for the amount ratio of FT to $\mathrm{FT}-{ }^{2} \mathrm{H}_{19}, x$ and the peak area ratio of FT to $\mathrm{FT}-{ }^{2} \mathbf{H}_{19}, \boldsymbol{y}$ was obtained. The calibration curve was expressed as $y=1.022 x+$ 0.027 with a correlation coefficient of $r=0.999$. The linear relationship was determined and the slope was almost equal to the case of serum. The reproducibility of the FT concentration in urine is shown in Table 1. The relative standard deviation (RSD) was $16.7 \%$ at the minimum quantifiable concentration $(0.4 \mathrm{ng} / \mathrm{ml}), 3.7 \%$ at $4 \mathrm{ng} / \mathrm{ml}$, and $3.0 \%$ at $40 \mathrm{ng} / \mathrm{ml}$.

The main metabolite of FT, Nor-FT has previously been measured by GC-MS ${ }^{11)-13)}$, GC using an $\mathrm{ECD}^{14)}$, and enzyme linked immunosorbent assay (ELISA) ${ }^{15)}$. However, these methods have mostly been used for detection of FT abuse, and are not accurate enough for pharmacokinetic studies.

We examined isotope dilution analysis of Nor-FT in urine using isotopic fractionation by capillary GC. Formerly, sensitive detection of Nor-FT was attempted by using an ECD after conversion to halogenated derivatives. However, the sensitivity and stability of this method were insufficient to determine the urine level of Nor-FT. The pentafluoropropionic derivative of Nor-FT was reported to have the highest sensitivity of the halogenic derivatives used for $\operatorname{ECD}^{14)}$, but the sensitivity was less than by use of SID, and reproducibility was insufficient due to interference with urinary compounds.

In our previous report ${ }^{10)}$, we demonstrated highly sensitive detection of FT by SID that was specific detector for the tertiary amino compound. However, Nor-FT is a secondary amino

Table 1 Reproducibility of FT concentration in urine

\begin{tabular}{cccccccc}
\hline \multirow{2}{*}{$\begin{array}{c}\text { Amount } \\
\text { added } \\
(\mathrm{ng} / \mathrm{ml})\end{array}$} & Sample 1 & Sample 2 & Sample 3 & Sample 4 & Sample 5 & Mean & RSD \\
\cline { 2 - 6 } & Samount found (ng/ml) & & \\
\hline 0.4 & 0.481 & 0.372 & 0.592 & 0.512 & 0.454 & 0.482 & $16.7 \%$ \\
4 & 3.89 & 3.50 & 3.68 & 3.67 & 3.68 & 3.68 & $3.7 \%$ \\
42 & 42.4 & 40.2 & 43.4 & 43.1 & 41.9 & 42.2 & $3.0 \%$ \\
\hline
\end{tabular}


compound, and $\mathrm{N}$-alkylation is necessary for detection by SID. The sensitivity of 3 kinds of $\mathrm{N}$-alkyl derivatives, Nor-FT-Me, Nor-FT-Et, and Nor-FT-Ben was compared. The relative sensitivity of Nor-FT-Me, Nor-FT-Et, and Nor-FT-Ben were $2.12,1.68$, and 0.59 , respectively, by comparison with FT after injection of $2 \mathrm{ng}$ of each into GC. These results demonstrate that the introduction of methyl or ethyl group to Nor-FT increase the sensitivity on SID analysis. Suzuki et al. reported this is due to an increase in surface ionization by the electron donating effect of the added groups ${ }^{16}$.

The isotopic fractionation of Nor-FT derivatives from their deuterium labeled analogues at column temperature $160-260^{\circ} \mathrm{C}$ or $220-270^{\circ} \mathrm{C}$ are shown in Fig. 2. The retention times of deuterium analogues were shorter than non-labeled analogues at all temperatures. We found linear relationships between resolution $\left(R_{s}\right)$ and the reciprocal of the absolute temperature $(1 / T)$, as shown in Fig. 3. The resolution of peaks $\left(R_{s}>1\right)$ within $30 \mathrm{~min}$ was achieved at $170-180^{\circ} \mathrm{C}$ for Nor-FT$\mathrm{Me}, 170-210^{\circ} \mathrm{C}$ for Nor-FT-Et, and $230-250^{\circ} \mathrm{C}$ for Nor-FT-Ben.

The determination of Nor-FT in spiked urine using ethyl derivative was not accurate, therefore, the methyl derivative was adopted in the determination of Nor-FT by the reason for its sensitivity, peak resolution and accuracy. The calibration curve was estimated from $1 \mathrm{ml}$ of the urine spiked with $10-400 \mathrm{ng}$ of Nor-FT and $200 \mathrm{ng}$ of Nor-FT- ${ }^{2} \mathrm{H}_{10}$ on $180^{\circ} \mathrm{C}$, and was expressed as $y=$ $1.372 x-0.044$ with a correlation coefficient of $r=0.999$. The slope of this line was differ from that of FT for overlapping the peaks $\left(R_{s}=1.1\right)$ in this column temperature. The methyl derivative yield was approximately $60 \%$ under these conditions.

The reproducibility of the Nor-FT concentra-
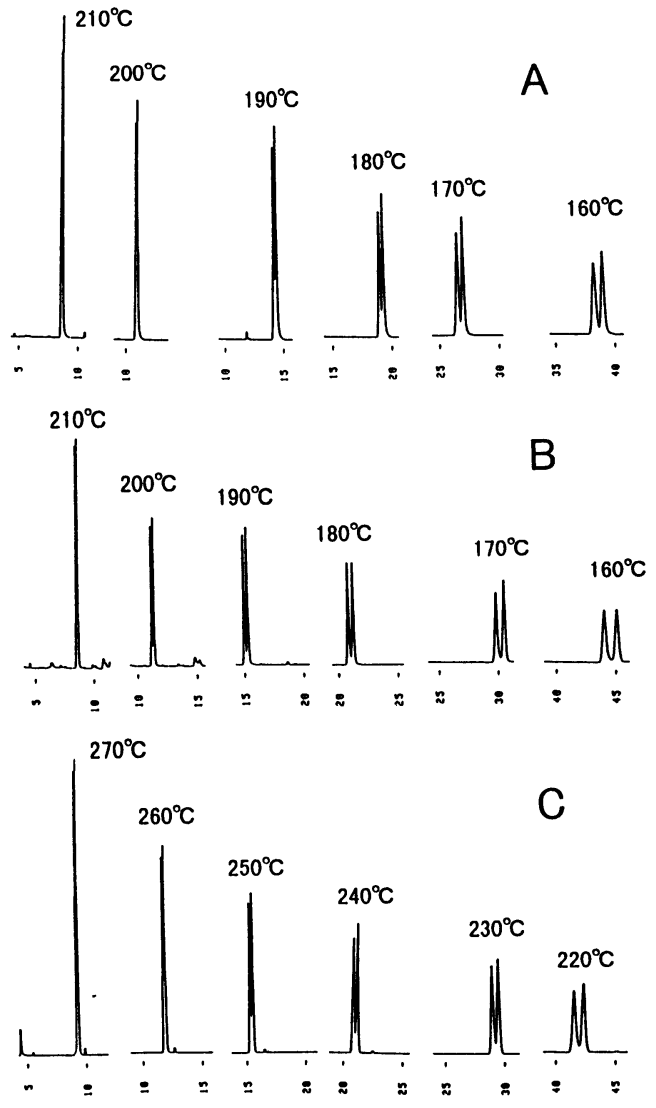

Fig. 2 Chromatograms of Nor-FT derivatives and their deuterated analogues Nor-FT-Me(A), Nor-FT-Et(B) and Nor-FT-Ben (C).

tion in urine is shown in Table 2. Intra-day precision was evaluated by analyzing the standard urine 5 times. The relative standard deviation (RSD) was $4.0 \%$ at the minimum quantifiable concentration $(10 \mathrm{ng} / \mathrm{ml})$.

To assess the possibility of formation of Nor-FT from FT during the derivation procedure, we examined the effect of FT concentration on the determination of Nor-FT. Nor-FT was measured in urine, which contained $200 \mathrm{ng} / \mathrm{ml}$ of Nor-FT and Nor-FT- ${ }^{2} \mathrm{H}_{10}$ and FT at a $0.1-2$ molar ratio to Nor-FT. The effect of FT on the determination of Nor-FT is shown in Fig. 4. Nor-FT concentration increased in relation to FT 


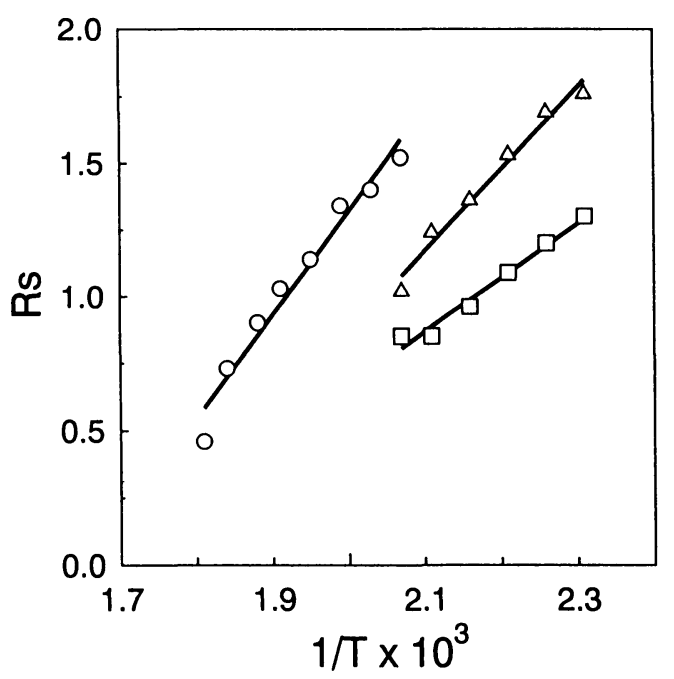

Fig. 3 Effect of column temperature ( $\mathrm{T}$ in Kelvin) on the separation of Nor-FT derivatives and their deuterated analogues.

Nor-FT-Me $(\square)$, Nor-FT-Et $(\triangle)$ and Nor-FT-Ben $(O)$

amount. Nor-FT was confirmed after treatment of FT $(50 \mu \mathrm{g})$ with dimethyl sulfate by GC-MS at same conditions. FT might have been degraded to Nor-FT by dimethyl sulfate treatment. Regardless of FT concentration, $25.4 \pm 7.8 \%(n=6)$ of FT was converted to Nor-FT. Since our previous report ${ }^{4}$ showed the urinary concentration of FT was lower than Nor-FT, the methyl derivation procedure might cause a slight change on Nor-FT concentration, especially at earlier time points after FT administration. Therefore, we corrected Nor-FT concentrations by subtracting the contribution of FT.

Typical gas chromatograms of the extracts

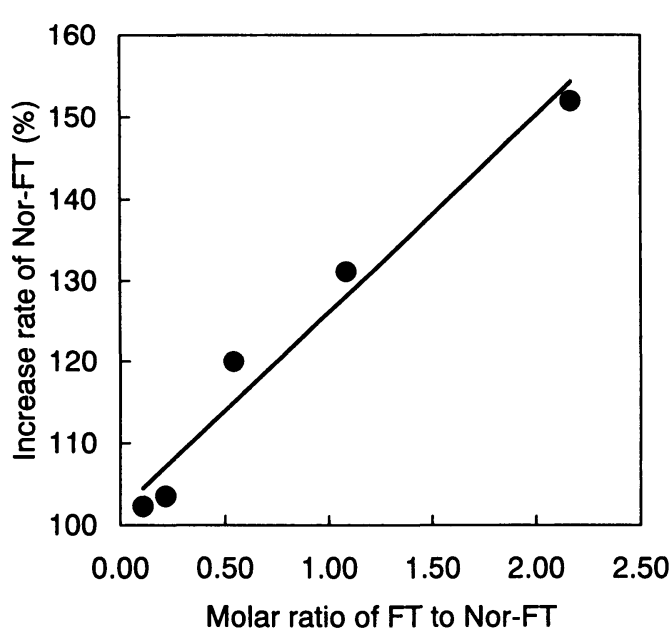

Fig. 4 Effect of FT on determination of Nor-FT in urine.

from patient urine after i.v. administration of FT are shown in Fig. 5. No endogenous compounds or concomitant drugs interfered with the detection of FT or Nor-FT. The urinary concentration of FT and Nor-FT are shown in Table 3. These results demonstrate the potential utility of this isotope dilution analysis for the clinical studies.

Individual differences in excretion rates of FT and Nor-FT were found, confirming to results from serum FT concentration studies ${ }^{10)}$. Recently, the $N$-dealkylation enzyme of FT has been identified as CYP3A4, in vitro ${ }^{17), ~ 18) ~ a n d ~ d r u g ~ i n t e r a c-~}$ tions in vivo with nifedipine ${ }^{19)}$, midazolam and triazolam $^{20)}$, erythromycin ${ }^{21)}$, lovastatin ${ }^{22)}$ and lodocaine ${ }^{23)}$, has been predicted. The present method will be useful for evaluation of these interactions in FT metabolism.

Table 2 Reproducibility of Nor-FT concentration in urine

\begin{tabular}{|c|c|c|c|c|c|c|c|}
\hline \multirow{2}{*}{$\begin{array}{l}\text { Amount } \\
\text { added } \\
\text { (ng/ml) }\end{array}$} & \multicolumn{5}{|c|}{ Amount found ( $\mathrm{ng} / \mathrm{ml}$ ) } & \multirow{2}{*}{ Mean } & \multirow{2}{*}{ RSD } \\
\hline & Sample 1 & Sample 2 & Sample 3 & Sample 4 & Sample 5 & & \\
\hline 10 & 12.85 & 12.15 & 12.72 & 11.75 & 11.93 & 12.28 & $4.0 \%$ \\
\hline 40 & 37.26 & 45.40 & 36.15 & 42.72 & 45.23 & 41.35 & $10.6 \%$ \\
\hline 399 & 371.3 & 419.1 & 429.8 & 393.5 & 407.4 & 404.2 & $5.6 \%$ \\
\hline
\end{tabular}


Table 3 Urinary concentration of FT and Nor-FT

\begin{tabular}{|c|c|c|c|c|c|c|}
\hline \multirow{3}{*}{$\begin{array}{l}\text { Time } \\
(\min )\end{array}$} & \multicolumn{3}{|c|}{ Subject A } & \multicolumn{3}{|c|}{ Subject B } \\
\hline & \multirow{2}{*}{$\begin{array}{c}\mathrm{FT} \\
(\mathrm{ng} / \mathrm{ml})\end{array}$} & \multicolumn{2}{|c|}{ Nor-FT (ng/ml) } & \multirow{2}{*}{$\underset{(\mathrm{ng} / \mathrm{ml})}{\mathrm{FT}}$} & \multicolumn{2}{|c|}{ Nor-FT (ng/ml) } \\
\hline & & Measured & Corrected & & Measured & Corrected \\
\hline $0-60$ & 0.37 & 0.0 & 0.0 & 1.54 & 10.3 & 10.1 \\
\hline $60-120$ & 8.03 & 84.1 & 82.7 & 1.81 & 46.3 & 45.9 \\
\hline $120-180$ & 4.97 & 86.6 & 85.7 & 1.75 & 50.5 & 50.2 \\
\hline $180-240$ & 2.49 & 63.7 & 63.2 & 0.36 & 39.5 & 39.4 \\
\hline $240-360$ & 0.59 & 52.8 & 52.7 & 0.59 & 20.8 & 20.7 \\
\hline $360-480$ & 1.74 & 71.1 & 70.8 & 1.61 & 51.1 & 50.8 \\
\hline
\end{tabular}

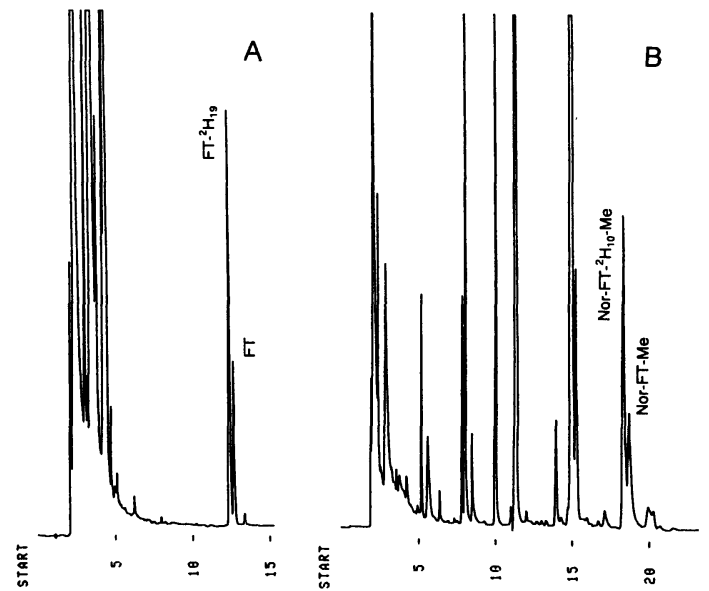

Fig. 5 Chromatograms of urine extracts from patients using the deuterated analogue $\mathrm{FT}-{ }^{2} \mathrm{H}_{19}(\mathrm{~A})$, of Nor- $\mathrm{FT}-{ }^{2} \mathrm{H}_{10}$ (B) as an internal standard. Collection time of urine after the administration of FT ( $5 \mu \mathrm{g} / \mathrm{kg}$ i.v.) : $60 \mathrm{~min}, \mathrm{FT} 7.27 \mathrm{ng} / \mathrm{ml}(\mathrm{A})$ and 480 min, Nor-FT $71.14 \mathrm{ng} / \mathrm{ml}(\mathrm{B})$.

\section{Acknowledgment}

We wish to express our appreciation to Dr.

Nozomu Yoshimura, Professor of Anesthesiology

\& Critical Care Medicine, School of Medicine, Kagoshima University, for his valuable advice and comments.

\section{References}

1) Goromaru, T., Matsuura, H., Furuta, T., Baba,
S., Yoshimura, N., Miyawaki, T. and Sameshima, T.: Identification of fentanyl metabolites in rat urine by gas chromatography-mass spectrometry with stable-isotope tracers., Drug Metab. Dispos., 10, 542-546 (1982)

2) Goromaru, T., Matsuura, H., Yoshimura, N., Miyawaki, T., Sameshima, T., Miyao, J., Furuta, T. and Baba, S.: Identification and quantitative determination of fentanyl metabolites in patients by gas chromatography-mass spectrometry, Anesthesiology, 61, 73-77 (1984)

3) Goromaru, T., Katashima, M., Matsuura, H. and Yoshimura, N.: Metabolism of fentanyl in isolated hepatocytes from rat and guinea pig, Chem. Pharm. Bull., 33, 3922-3928 (1985)

4) Goromaru, T., Kawauchi, T., Katashima, M., Matsuura, H., Yoshimura, N., Sameshima, T. and Miyawaki, T.: Urinary excretion of fentanyl and its metabolites at high-dose infusion, Masui, 35, 35-39 (1986)

5) Goromaru, T., Ikejiri, H., Hashimoto, K. and Matsuki, Y.: Isotopic fractionation of iproniazid and isopropylhydrazine from their deuterated analogues and application for isotope dilution analysis by capillary gas chromatography, Yakugaku Zasshi, 111, 612-616 (1991)

6) Goromaru, T., Maeda, H., Matsuki, Y. and Kiwada, H. : Isotopic fractionation of aminopyrine from its deuterated analogues and application for evaluation of hepatic function by capillary gas chromatography, Radioisotopes, 42, 511-516 (1993)

7) Goromaru, T. and Maeda, H.: Isotopic fractionation of isopropylantipyrine and its deuterated analogues by capillary gas chromatography., Biol. Pharm. Bull., 17, 1635-1639 (1994)

8) Goromaru, T., Sera, S. and Ikeda, H.: Isotopic 
fractionation of benzoic acid and hippuric acid from their deuterated analogues by high performace liquid chromatography, Radioisotopes, 44, 693-700 (1995)

9) Sera, S. and Goromaru, T.: Isotopic fractionation of fentanyl and its deuterated analogues by capillary gas chromatography, ibid., 46, 885-892 (1997)

10) Sera, S., Goromaru, T., Sameshima, T., Kawasaki, K. and Oda, T.: Quantification of fentanyl in serum by isotopic dilution analysis using capillary gas chromatography, ibid., 47, 480-487 (1998)

11) Guitton, J., Desage, M., Alamercery, S., Dutruch, L., Dautraix, S., Perdrix, J. P. and Brazier, J. L. : Gas chromatographic-mass spectrometry and gas chromatographic-Fourier transform infrared spectroscopy assay for the simultaneous identification of fentanyl metabolites [In Process Citation], $J$. Chromatogr. B, 693, 59-70 (1997)

12) Silverstein, J. H., Rieders, M. F., McMullin, M., Schulman, S. and Zahl, K.: An analysis of the duration of fentanyl and its metabolites in urine and saliva., Anesth. Analg., 76, 618-621 (1993)

13) Schwartz, J. G., Garriott, J. C., Somerset, J. S., Igler, E. J., Rodriguez, R. and Orr, M. D. : Measurements of fentanyl and sufentanil in blood and urine after surgical application. Implication in detection of abuse, Am. J. Forensic Med. Pathol., 15, 236-241 (1994)

14) Hammargren, W. R. and Henderson, G. L.: Analyzing normetabolites of the fentanyls by gas chromatography/electron capture detection, J. Anal. Toxicol., 12, 183-191 (1988)

15) Makowski, G. S., Richter, J. J., Moore, R. E., Eisma, R., Ostheimer, D., Onoroski, M. and Wu, A. H. : An enzyme-linked immunosorbent assay for urinary screening of fentanyl citrate abuse., Ann. Clin. Lab. Sci., 25, 169-178 (1995)

16) Suzuki, S., Tsuchihashi, H. and Arimoto, H.: Studies on 1-(2-phenethyl)-4-( $N$-propionylanilino) piperidine (fentanyl) and related compounds III. Effect of methyl group introduction into fentanyl on sensitivity enhancement in gas chromatography with surface ionization detection, J. Chromatogr., 475, 400-403 (1989)

17) Tateishi, T., Krivoruk, Y., Ueng, Y. F., Wood, A. J., Guengerich, F. P. and Wood, M.: Identification of human liver cytochrome P-450 3A4 as the enzyme responsible for fentanyl and sufentanil N-dealkylation, Anesth. Analg., 82, 167-172 (1996)

18) Feierman, D. E. and Lasker, J. M. : Metabolism of fentanyl, a synthetic opioid analgesic, by human liver microsomes. Role of CYP3A4, Drug Metab Dispos, 24, 932-939 (1996)

19) Guengerich, F. P., Martin, M. V., Beaune, P. H., Kremers, P., Wolff, T. and Waxman, D. J.: Characterization of rat and human liver microsomal cytochrome P-450 forms involved in nifedipine oxidation, a prototype for genetic polymorphism in oxidative drug metabolism., J. Biol. Chem., 261, 5051-5060 (1986)

20) Kronbach, T., Mathys, D., Umeno, M., Gonzalez, F. J. and Meyer, U. A.: Oxidation of midazolam and triazolam by human liver cytochrome P450 IIIA4, Mol. Pharmacol, 36, 89-96 (1989)

21) Watkins, P. B., Wrighton, S. A., Maurel, P., Schuetz, E. G., Mendez-Picon, G., Parker, G.A. and Guzelian, P.S. : Identification of an inducible form of cytochrome P-450 in human liver, Proc. Natl. Acad. Sci. USA, 82, 6310-6314 (1985)

22) Wang, R. W., Kari, P. H., Lu, A. Y., Thomas, P. E., Guengerich, F. P. and Vyas, K. P.: Biotransformation of lovastatin. IV. Identification of cytochrome P450 3A proteins as the major enzymes responsible for the oxidative metabolism of lovastatin in rat and human liver microsomes., Arch. Biochem. Biophys., 290, 355-361 (1991)

23) Imaoka, S., Enomoto, K., Oda, Y., Asada, A., Fujimori, M., Shimada, T., Fujita, S., Guengerich, F. P. and Funae, Y.: Lidocaine metabolism by human cytochrome $\mathrm{P}-450$ s purified from hepatic microsomes : comparison of those with rat hepatic cytochrome P-450s, J. Pharmacol. Exp. Ther., 255, 1385-1391 (1990) 
要旨

\title{
キャピラリガスクロマトグラフィを用いた同位体希釈分析による患者尿中 フェンタニルおよび主代謝物ノルフェンタニルの定量
}

世良庄司, 五郎丸 毅, 鮫島照子*, 川崎孝一*, 小田利通*

\author{
福山大学薬学部 \\ 729-0292 広島県福山市学園町一番地三蔵 \\ $*$ 鹿児島大学医学部 \\ 890-0075 鹿児島県鹿児島市桜ヶ丘 8-35-1
}

安定同位体希釈分析により，麻薬性鎮痛薬フェンタニル (FT) とその主代謝物である Nor-FT の 尿中濃度を測定した。19 個の重水素を標識した FT $-{ }^{2} \mathrm{H}_{19}$ と FT は, 表面電離型イオン化検出器 (SID) 装備キャピラリ GCにより分離測定可能であり，尿中 FT を $0.4-40 \mathrm{ng} / \mathrm{ml}$ の範囲で再現 性よく測定できた。Nor-FT は二級アミンであり SID では高感度検出ができないが, $N$-アルキル 誘導体化により三級アミンとすることで高感度検出を試みた。3 種類の誘導体を用い分離, 感度, 再現性から検討したところ, $N$-メチル誘導体が最適であった。尿中の Nor-FT を $10-400 \mathrm{ng} / \mathrm{ml}$ の範囲で Nor-FT- ${ }^{2} \mathrm{H}_{10}$ を用い誘導体化後測定したところ, 優れた直線性と良好な再現性が得られ た。FT 投与患者尿中の FT および Nor-FT の測定を行ったところ, 生体内物質や併用薬物の影響 を受けず正確な測定が可能であり，FT の体内動態解析に有用であると考えられる。 